\title{
PENERAPAN METODE TUTOR SEBAYA UNTUK MENINGKATKAN HASIL BELAJAR PESERTA DIDIK PADA PEMBELAJARAN MATEMATIKA KONSEP PERKALIAN SKALAR DUA VEKTOR
}

\author{
Yustina Rini Purwantati
}

Sma Swasta Katolik Bhaktyarsa

E-mail: riniyustina@gmail.com

\begin{abstract}
ABSTRAK
Penelitian ini bertujuan untuk meningkatankan kompetensi professional pendidik dan meningkatkan prestasi hasil belajar peserta didik pada mata pelajaran matematika dengan menggunakan metode pembelajaran tutor sebaya. Subjek penelitian ini adalah peserta didik Semester 2 MIPA 2 SMAS Katolik Bhaktyarsa Maumere. Data dalam penelitian ini diperoleh melalui pengamatan, ketrampilan berdiskusi peserta didik dengan tutorial, dan tes hasil akhir peserta didik. Data dianalisis secara kuantitatif dan kualitatif diskriptif. Hasil penelitian yang diperoleh yaitu persentase keaktifan peserta didik, ketelitian dalm penyelesaian soal dan ketuntasan belajar dan produk mengalami peneingkatan pada setiap siklus. Kemampuan rata-rata peserta didik sebelum adanya implementasi tindakan berkategori kurang. Namun, setelah implementasi tindakan selama dua siklus, kemampuan rata-rata peserta didik menjadi berkategori baik. Hasil penelitian menunjukan (1) secara proses, pembelajaranmatematika konsep perkalian scalar dua vector mengalami peningkatan yang signifikan. Sebelum implementasi tindakan, peserta didik masih belum aktif melakukan diskusi dan belum mampu bekerjasama dengan baik pada saat berdiskusi. Setelah implementasi tindakan, peserta didik menjadi aktif dan mampu bekerjasama dengan baik pada saat berdiskusi; (2) secara produk, dalam menyeleseiakan soal perkalian scalar dua vector memperoleh skor rata-rata 86,67 untuk siklus I dan 89,92 untuk siklus II. Peningkatan prestasi belajar antar siklus yang diperoleh adalah $8,67 \%$ untuk ketuntasan klasikal dan 3,25 untuk rata-rata kelas.
\end{abstract}

Kata kunci: Tutor Belajar, Hasil belajar Matematika, Konsep Perkalian Skalar dua Vektor

\begin{abstract}
This study aims to improve the professional competence of educators and improve the achievement of student learning outcomes in mathematics by using peer tutoring learning methods. The subjects of this study were students of the 2nd Semester MIPA 2 Bhaktyarsa Maumere Catholic SMAS. The data in this study were obtained through observation, students 'discussion skills with tutorials, and students' final results tests. Data were analyzed quantitatively and qualitatively descriptive. The results obtained were the percentage of student activity, accuracy in solving problems and completeness of learning and the product experienced an increase in each cycle .. The average ability of students before the implementation of actions categorized as less. However, after the implementation of the action for two cycles, the average ability of students became a good category. The results of the study show: (1) in the process, mathematics learning on the two vector scalar multiplication concept has experienced a significant increase. Before the implementation of the action, students were still not active in conducting discussions and had not been able to cooperate well when discussing. After the implementation of the
\end{abstract}


action, students become active and able to cooperate well when discussing; (2) by product, in completing the two vector scalar multiplication problems the average score is 86.67 for cycle I and 89.92 for cycle II. The increase in inter-cycle learning achievement obtained was $8.67 \%$ for classical completeness and 3.25 for the class average.

Keywords: Learning Tutors, Mathematics Learning Outcomes, Concepts of Scalar Multiplication of two Vectors

\section{PENDAHULUAN}

$\begin{array}{clcc}\text { Kegiatan } & \text { utama dalam } & \text { proses } \\ \text { pendidikan di } & \text { sekolah adalah } & \text { proses }\end{array}$ pembelajaran. Pembelajaran ibarat jantung dari proses pendidikan (Indrianie, 2015). Pembelajaran yang baik, cenderung menghasilkan lulusan dengan hasil belajar yang baik, demikian pula sebaliknya. Menurut Asmani (2011), pembelajaran adalah suatu proses yang melibatakan serangkaian kegiatan guru dan peserta didik, atas dasar hubungan timbal balik yang berlangsung dalam kondisi edukatif, untuk mencapai tujuan tertentu. Proses pembelajaran merupakan interaksi semua komponen atau unsur yang terdapat dalam pembelajaran, yang satu sama lain saling berhubungan dalam rangkaian untuk mencapai tujuan. Dengan demikian, pembelajaran merupakan salah satu unsur penentu baik tidaknya lulusan yang dihasilkan oleh suatu sistem pendidikan. Menurut Sonhaji (2007), kegiatan pembelajaran adalah suatu aktivitas untuk mentransformasikan bahan pelajaran kepada subjek belajar.

Peserta didik diharapkan mengalami perubahan baik dalam bidang pengetahuan, pemahaman, ketrampilan, nilai dan sikap. Pendidik merupakan salah satu faktor pendukung dalam menentukan keberhasilan peserta didik dalam dunia pendidikan. Oleh karena itu pendidik harus bisa melakukan inovasi dalam proses pembelajaran. Inovasi pendidik dapat berupa penggunaan model, metode dan media pembelajaran yang relevan dengan kehidupan dan pengalaman peserta didik, supaya pembelajaran menjadi lebih bermakna. Peserta didik menjadi aktif dan kreatif dalam mengikuti proses pembelajaran.

Matematika merupakan ilmu universal yang mendasari perkembangan teknologi modern dan mempunyai peranan penting dalam berbagai disiplin ilmu dan memajukan daya pikir manusia. Dalam penguasaan ilmu dan terapan teknologi di masa depan diperlukan penguasaan materi matematika dengan benar sejak dini. Hal ini karena, matematika yang diajarkan di sekolah menuntut siswa dibutuhkan suatu pemikiran dengan cara berfikir logis. Pembelajaran matematika di sekolah berkembang dengan cepat sesuai tuntutan ilmu pengetahuan dan teknologi dalam rangka memudahkan siswa memahami dengan baik materi yang diajarkan guru (Nurmal, 2017)

Materi pelajaran matematika kurang diminati oleh peserta didik, karena dianggap pelajaran yang sulit dan penuh dengan angka. Proses pembelajaran matematika masih lebih menekankan pada metode diskusi informasi dan pemberian tugas, mengakibatkan peserta didik kurang aktif, jarang mengajukan pertanyaan, dan kurang mengerti materi. Pembelajaran matematika menjadi pelajaran yang tidak menyenangkan, membosankan, dan mengakibatkan rendahnya hasil evaluasi belajar matematika.

Pengalaman peneliti dalam mengajar matematika pada semester 2 MIPA 1 SMAS Bhaktyarasa tahun pembelajaran 2016/2017 menunjukkan bahwa sebagian peserta didik mengalami kesulitan dalam memahami materi perkalian scalar dua vector pada ruang dimensi 2 dan dimensi 3, padahal materi ini sangat penting dan menjadi prasyarat dalam mempelajari sudut antara dua vector dan proyeksi vector. Berdasarkan hasil post tes secara klasikal tingkat ketuntasan yang dicapai hanya $51,9 \%$ 
dengan KKM 75. Dari 27 peserta didik hanya 15 yang mendapat nilai di atas 75 dan 12 orang di bawah 75 .

Dari uraian di atas dapat diidentifikasi masalah-masalah yang timbul dalam proses pembelajaran : 1) Peserta didik kurang berminat terhadap pelajaran matematika karena pelajaran matematika kurang menarik sehingga mereka mudah bosan dan kadang mengobrol dengan temannya, 2) Metode pembelajaran diskusi informasi dan penugasan kurang memotivasi peserta didik untuk aktif dalam proses pembelajaran. Untuk mengantisipasi permasalahan tersebut, perlu dicarikan formula yang tepat sehingga dapat meningkatkan keaktifan peserta didik dalam pembelajaran matematika. Metode pembelajaran yang dapat meningkatkan ketrampilan berpikir peserta didik secara aktif dan kreatif salah satunya adalah metode tutor sebaya dengan cara peserta didik yang pandai dapat memberi bantuan belajar kepada peserta didik yang kurang pandai. Oleh karena itu penerapan metode tutor sebaya diharapkan dapat membantu pendidik dalam mengajarkan materi kepada peserta didik, karena dalam hal tertentu kadang peserta didik lebih paham dengan bahasa teman sebaya daripada bahasa pendidik, dan peserta didik tidak merasa malu dan takut untuk menayakan materi yang belum mereka pahami.

Proses pembelajaran seharusnya menempatkan siswa sebagai subyek yang mempunyai potensi dasar masing-masing yang dapat berkembang bukan sebagai obyek yang hanya dapat dibentuk semau pendidik. Mereka membutuhkan dorongan eksternasl untuk menumbuhkembangkan potensi internal siswa.

Setiap pendidik harus memiliki pemahaman bahwa semua siswa memiliki kelebihan atau potensi yang bervareasi untuk berhasil. Jadi keberhasilan itu merupakan sebuah permata yang dapat menjadi milik semua orang. Keanekaragaman potensi atau kemampuan yang dimiliki siswa dalam memahami sebuah konsep sering menimbulkan masalah, antara lain kadang ada siswa yang sangat cepat memahami dan ada yang merasakan kesulitan tetapi merekan segan bahkan merasa takut untuk bertanya kepada guru, apa lagi kalau guru tersebut kurang menyenangkan.

Kesulitan yang dialami oleh sekelompok siswa tersebut dapat diatasi dengan cara melibatkan teman sebayanya dalam pembelajaran atau guru menerapkan model pembelajaran tutor sebaya. Strategi belajar dengan tutor sebaya adalah strategi belajar secara dini dalam upaya mengantisipasi kesulitan-kesulitan yang dihadapi siswa agar tidak berdampak lebih jauh terhadap pengaruh yang cukup signifikan terhadap kemampuan siswa dalam menguasai kompetensi yang seharusnya dicapai dan berdampak terhadap prestasi belajar siswa.

Tutor ada dua macam yaitu tutor sebaya dan tutor kakak. Tutor sebaya adalah teman sebaya yang lebih pandai, sedang tutor kakak adalah tutor dari kelas yang lebih tinggi. Menurut Dedi Supriyadi (1985. h. 36) mengemukakan bahwa,Tutor Sebaya adalah seorang atau beberapa orang siswa yang ditunjuk dan ditugaskan untuk membantu siswa yang mengalami kesulitan belajar. Tutor tersebut diambil dari kelompok yang prestasinya lebih tinggi. Ischak dan Warji (1987, h. 44) mengemukakan bahwa Tutor Sebaya adalah sekelompok siswa yang telah tuntas terhadap bahan pelajaran, memberikan bantuan kepada siswa yang mengalami kesulitan dalam memahami bahan pelajaran yang dipelajarinya. Cony Semiawan, dkk (1987, h. 70) mengemukakan bahwa Tutor Sebaya adalah siswa yang pandai dapat memberikan bantuan belajar kepada siswa yang kurang pandai. Bantuan tersebut dapat dilakukan kepada teman-teman sekelasnya di luar sekolah. Jadi dari beberapa pendapat tokoh diatas maka tutor sebaya dapat diartikan sebagai sumber belajar selain guru, yaitu teman sebaya yang lebih pandai memberikan bantuan belajar kepada temanteman sekelasnya di sekolah. Menurut Hisyam Zaini (2001:1) (dalam Amin Suyitno, 2004:34), langkah-langkah dalam menerapkan pembelajaran tutor sebaya adalah sebagai berikut: 1) Pilih materi yang memungkinkan materi tersebut dapat dipelajari siswa secara mandiri. Materi 
pengajaran dibagi dalam sub-sub materi (segmen materi), 2) Bagilah para siswa menjadi kelompok-kelompok kecil yang heterogen, sebanyak sub-sub materi yang akan disampaikan guru. Siswa-siswa pandai disebar dalam setiap kelompok dan bertindak sebagai tutor sebaya, 3) Masingmasing kelompok diberi tugas mempelajari satu sub materi. Setiap kelompok dibantu oleh siswa yang pandai sebagai tutor sebaya, 4) Beri mereka waktu yang cukup untuk persiapan, baik di dalam kelas maupun di luar kelas, 5) Setiap kelompok melalui wakilnya menyampaikan sub materi sesuai dengan tugas yang telah diberikan. Guru bertindak sebagai nara sumber utama, 6) Setelah semua kelompok menyampaikan tugasnya secara barurutan sesuai dengan urutan sub materi, beri kesimpulan dan klarifikasi seandainya ada pemahaman siswa yang perlu diluruskan.

Berdasarkan latar belakang masalah di atas penulis bermaksud mengadakan penelitian dengan judul : "Penerapan Metode Tutor Sebaya untuk Meningkatkan Prestasi Belajar pada Pembelajaran Matematika Konsep Perkalian Skalar Dua Vektor bagi Peserta Didik Semester 2 MIPA SMA Swasta Katolik Bhaktyarsa Tahun 2018".

\section{METODE PENELITIAN}

Penelitian ini adalah penelitian tindakan kelas. Subyek dalam penelitian ini adalah peserta didik Semester 2 MIPA SMA Swasta Katolik Bhaktyarsa, sebanyak 25 orang. Alasan memilih kelas tersebut karena peserta didiknya kurang minat belajar matematika dan nilai kurang maksimal. Penelitian dilaksanakan di SMA Swasta Katolik Bhaktyarsa yang terletak di Jln Jendral Achmad Yani no. 31 Maumere, dikarenakan sekolah ini adalah tempat mengajar peneliti sehingga secara teknis dan operasional lebih mudah. Penulis merencanakan pelaksanaan penelitian minggu ke 4 Bulan Januari sampai Minggu ke 4 Bulan Maret 2018.

Pengumpulan data dilakukan pada siklus 1 dan 2 yang berupa penilaian pengetahuan hasil evaluasi pembelajaran dan hasil observasi pembelajaran. Alat yang digunakan dalam proses pengumpulan data adalah melalui instrumen penilaian dan pedoman observasi. Teknik pengumpulan data pada penelitian ini adalah: 1. Observasi, observasi dilaksanakan oleh peneliti dengan mengamati proses pembelajaran dikelas saat guru tengah memberikan materi pelajaran. Observasi hanya dilakukan sebatas mengamati, mengidentifikasi, dan mencatat apa kekurangan dan kelebihan dalam proses pembelajaran. Data yang dihasilkan dari kegiatan observasi berupa catatan lapangan yang mendeskripsikan proses pembelajaran saat observasi siklus I dan siklus II dilakukan, 2. Dokumentasi, dokumentasi merupakan upaya untuk memberikan gambaran bagaimana sebuah penelitian tindakan kelas dilakukan. Kegiatan ini dilaksanakan dengan mengambil gambar kegiatan para peserta didik dan pendidik dalam pelaksanaan pembelajaran saat penelitian dilaksanakan. Data yang dihasilkan dari kegiatan ini berupa gambar atau foto kegiatan pembelajaran, 3. Tes, tes merupakan alat yang digunakan peneliti untuk mengetahui hasil dari penelitian yang telah dilakukan. Tes dilakukan adalah tes tertulis dan hasil pengamatan waktu kegiatan kelompok bersama tutor. Data yang didapatkan dari kegiatan ini adalah tabel pengamatan berupa hasil belajar atau nilai ujian peserta didik dan skor penilaian keaktifan yang digunakan sebagai indikator ketercapaian hasil penelitian.

Penelitian ini dilaksankan dalam dua siklus. Tiap siklus memiliki prosedur penelitian. Prosedur penelitian merupakan tahapan-tahapan yang ditempuh dalam penelitian dari awal sampai akhir secara urut. Prosedur penelitian ini terdiri dari beberapa tahap kegiatan yaitu: Tahap Pra Siklus, kegiatan yang dilakukan oleh peneliti pada tahap ini adalah mengambil data ratarat nilai post test konsep perkalian scalar dua 
vector pada peserta didik semester 1 MIPA tahun pembelajaran 2016/2017, 2) Siklus 1, dan 3) Siklus 2. Adapun langkah-langkah pada siklus 1 dan 2 adalah a) Perencanaan, Pelaksanaan, c. Observasi, d. Refleksi.

Pengumpulan data dilakukan pada siklus 1 dan 2 yang berupa penilaian pengetahuan hasil evaluasi pembelajaran dan hasil observasi pembelajaran. Alat yang digunakan dalam proses pengumpulan data adalah melalui instrumen penilaian dan pedoman observasi.

Analisis data dilakukan dengan cara kuantitatif dan kualitatif diskriptif. Analisis data dilakukan pada akhir pembelajaran atau siklus. Dalam beberapa kali pertemuan dapat dihasilkan solusi yang berguna untuk menentukan rencana tindakan pada siklus penelitian berikutnya. Proses analisis dalam penelitian ini dilakukan melalui beberapa tahap yaitu: 1. Pengelompokan Data, data yang diperoleh disusun, kemudian dikelompokan untuk memudahkan analisis .Kelompok-kelompok tersebut adalah aktivitas selama pembelajaran.Data yang sudah dikelompokkan digunakan sebagai pertimbangan dalam menjawab" Mengapa prestasi belajar peserta didik rendah " dan bagaimana cara meningkatkan prestasi belajar peserta didik tersebut ?, 2. Interprestasi, data yang telah terkumpul dalam penelitian ini diinterprestasikan ,untuk mencari gambaran benarkah "Penerapam metode tutor sebaya dapat meningkatkan prestasi belajar peserta didik dalam pembelajaran matematika konsep perkalian scalar dua vektor ? ". Apabila terjadi peningkatan nilai, maka penelitian dianggap selesai dan berhasil, tetapi jika tidak terjadi peningkatan, maka hasil penelitian ini dapat dijadikan referensi untuk melakukan penelitian selanjutnya bagi peneliti lain..

\section{HASIL DAN PEMBAHASAN}

Proses penelitian ini dilakukan dalam dua siklus yang masing-masing siklus terdiri dari 4 tahapan, yaitu : (1) perencanaan tindakan, (2) pelaksanaan tindakan, (3) observasi dan interpretasi, dan (4) analisis dan refleksi tindakan.

\section{Siklus Pertama}

Penerapan pembelajaran matematika konsep perkalian scalar dua vector pada siklus pertama melalui metodeTutor Sebaya adalah : 1) Kegiatan perencanaan Tindakan Pertama dilaksanakan pada hari Selas 23 Januari 2018. Setelah mengadakan pengamatan peneliti menemukan permasalahan peserta didik Semester 2 MIPA dalam pemahaman materi dan masih rendahnya tingkat keaktifan peserta didik serta kurangnya minat mengikuti pelajaran matematika yang mengakibatkan prestasi belajar rendah. Maka peneliti merencanakan akan melaksanakan tindakan pada siklus pertama pada hari Selasa 13 Maret 2018.

Pelaksanaan tindakan pertama dilaksanakan pada hari Selasa 13 Maret 2018 dan 20 Maret 2018 di ruang semester 2 MIPA 2. Pertemuan dilaksanakan selama $3 \mathrm{x}$ 45 menit sebanyak dua kali sesuai dengan skenario pembelajaran dan RPP. Materi pada pelaksanaan tindakan pertama ini adalah Perkalian Skalar Dua Vektor pada ruang dimensi dua ( bidang). Pendidik yang juga peneliti menjelaskan konsep materi, membentuk kelompok belajar, dan memberikan latihan soal untuk dikerjakan kelompok dan mengadakan evaluasi.

3) Observasi dan Interpretasi, Peneliti bertindak sebagai pengajar dan pendidik mata pelajaran matematika yang juga bertindak sebagai pengamat/ observer yang bertugas mencatat aktivitas peserta didik dan memberikan penilaian berdasarkan lembar observasi yang telah dibuat. Berdasarkan hasil pengamatan terhadap pelaksanaan proses belajar mengajar matematika , diperoleh gambaran tentang aktivitas peserta didik selama kegiatan belajar mengajar berlangsung, yaitu sebagai berikut: (1) Peserta didik yang aktif selama pemberian apersepsi 14orang atau sebesar $58,44 \%$, sedangkan $41,56 \%$ lainnya masih belum dapat memusatkan perhatian pada awal pembelajaran, (2) Peserta didik yang aktif dalam kelompok selama kegiatan kerja kelompok berlangsung 17 orang atau sebesar $79.17 \%$, sedangkan $20,83 \%$ lainnya 
kurang kompak dan tidak saling membantu dalam kelompok. Hal ini disebabkan karena peserta didik tidak bisa mengerjakan dan tidak aktif dalam berdiskusi karena kurangnya motivasi dalam diri mereka, (3) Peserta didik yang dapat mengerjakan tugas dari pendidik dengan tepat dan teliti sebesar $70,83 \%$ sedangkan yang lainnya masih ada yang tidak lengkap dan belum bisa mengerjakan soal dengan sempurna, (4)

Berdasarkan hasil evaluasi tes akhir siklus I dapat diidentifikasi bahwa peserta didik yang sudah mencapai ketuntasan (KKM 75 ) materi perkalian scalar dua vector pada ruang dimensi dua sebesar $80 \%$ sedangkan $20 \%$ peserta didik lainnya belum tuntas. Hal ini disebabkan mereka masih kesulitan dalam memahami materi dan kurang teliti dalam pengerjaan soal.

Berdasarkan hasil observasi dan interpretasi tindakan pada siklus pertama, Beberapa kelemahan pendidik dalam siklus pertama ini adalah: a) Masih banyak peserta didik merasa segan bertanya langsung pada pendidik pada saat pembelajaran, tetapi baru mau mengemukakan pendapat setelah ditunjuk langsung oleh Pendidik. Mereka merasa lebih nyaman bertanya kepada Pendidik apabila mendekati mereka (seperti pada saat monitoring), b) Pendidik dalam menjelaskan materi dan memberikan contoh pengerjaan soal terlalu cepat sehingga sulit untuk diikuti, c) Pendidik belum memberikan penghargaan kepada pesrta didik yang mampu menyelesaikan tugas dengan benar, teliti, dan lebih cepat daripada peserta didik yang lain, d) Pendidik tidak memberikan batasan waktu mengerjakan latihan dengan tutor, sehingga peserta didik juga santai dalam mengerjakan latihan.

2. Siklus Kedua

Penerapan pembelajaran matematika konsep perkalian scalar dua vector pada siklus kedua melalui metode tutor sebaya yang pertama dilakukan adalah kegiatan perencanaan. Kegiatan perencanaan tindakan kedua dilaksanakan pada hari Selasa tanggal 17 April 2018. Pendidik merancang tindakan yang akan dilakukan dalam penelitian selanjutnya. Berdasarkan hasil analisis dan refleksi dari siklus pertama terdapat beberapa kekurangan, kemudian akan dilaksanaan tindakan pada siklus kedua pada hari Selasa tanggal 24 April 2018.

Kegiatan pelaksanaan tindakan kedua dilaksanakan pada hari Selasa tanggal 24 April 2018 di ruang semester 2 MIPA 2. Pertemuan dilaksanakan selama $3 \times 45$ menit sesuai dengan skenario pembelajaran dan RPP. Pelaksanaan tindakan kedua hampir sama dengan pelaksanaan tindakan pertama, hanya pada pelaksanaan tindakan kedua ini terdapat perbaikan/penguatan yang masih diperlukan dari tindakan pertama. Materi yang disampaikan pada pelaksanaan tindakan kedua berbeda dengan pelaksanaan tindakan pertama, yaitu hasilkali scalar dua vector pada ruang dimensi tiga.

Pada Siklus kedua pendidik mendemonstrasikan penggunaan rumus hasilkali scalar dua vector pada ruang dimensi tiga dan dibuka kesempatan tanya jawab, peserta didik mengerjakan soal latihan secara berkelompok yang masih dengan metode yang diterapkan di Siklus pertama, presentasi hasil diskusi dan tes untuk mengetahui hasil belajar pesrta didik.

Berdasarkan hasil observasi terhadap pelaksanaan proses belajar mengajar matematika, diperoleh informasi tentang aktivitas pesrta didik selama kegiatan belajar mengajar berlangsung, yaitu sebagai berikut: 1) Pesrta didik yang aktif selama pemberian apersepsi sebesar 80\%, sedangkan $20 \%$ lainnya belum secara optimal dalam persiapan mengikuti pelajaran, 2) Pesrta didik yang aktif selama kegiatan belajar mengajar berlangsung sebesar 92\%, sedangkan $8 \%$ lainnya masih belum bisa berkonsentrasi dan bekerjasama dengan anggota kelompok yang lain, 3) Pesrta didik yang dapat mengerjakan latihan soal dari pendidik dengan tepat dan teliti sebesar $88 \%$, sedangkan $12 \%$ lainnya belum secara tepat dan teliti mengerjakan latihan soal yang diberikan, hal ini dikarenakan, pesrta didik tersebut belum paham dan tidak mau bertanya pada saat diberi kesempatan untuk bertanya, 4) Berdasarkan hasil evaluasi akhir pesrta didik dapat diidentifikasi bahwa pesrta didik yang sudah mampu mengerjakan soal hasilkali scalar dua vector dimensi tiga sudah dapat mencapai nilai 75 ke atas sebesar $92 \%$ atau sebanyak 23 pesrta 
didik, sedangkan $8 \%$ atau 2 pesrta didik lainnya masih belum sempurna dalam menyelesaikan soal evaluasi yang diberikan. Hal ini disebabkan mereka kurang teliti dalam memahami soal yang diberikan.

Kelemahan pendidik dalam siklus kedua ini adalah: a) Pendidik sudah dapat memahami kondisi konsentrasi pesrta didik meskipun masih ada peserta didik yang kurang konsentrasi, karena alasan sakit. Sedangkan dari segi peserta didik ditemukan beberapa kekurangan, yaitu sebagai berikut: a) Masih terdapat peserta didik yang belum bisa bekerjasama dengan anggota dalam kelompok, b) Dari segi hasil belajar, peserta didik yang mendapatkan nilai 75 ke atas, sudah mencapai 23 peserta didik dan nilai rata-rata kelas juga sudah mengalami kenaikan. Dari hasil perhitungan, nilai ratarata kelas mencapai 89,92. Nilai ini sudah di atas nilai KKM. Sehingga dianggap pembelajaran sudah mencapai titik ketuntasan, meskipun belum $100 \%$ peserta didik dinyatakan tuntas belajar.

Berdasarkan hasil pelaksanaan tindakan pada siklus pertama dan kedua dapat dinyatakan bahwa terjadi peningkatan prestasi belajar matematika konsep perkalian scalar dua vector menggunakan metode tutor sebaya dari siklus satu ke siklus berikutnya. Hal tersebut dapat dilihat dari tabel berikut ini:

Tabel Hasil Penelitian

\begin{tabular}{|l|l|l|}
\hline Aspek yang dinilai & Siklus & Prosentase \\
\hline $\begin{array}{l}\text { Keaktifan peserta didik selama } \\
\text { apersepsi }\end{array}$ & Siklus I & $\frac{14}{24} \times 100 \%=58,44 \%$ \\
\cline { 2 - 3 } & Siklus II & $\frac{20}{25} \times 100 \%=80 \%$ \\
\hline $\begin{array}{l}\text { Keaktifan dalam kelompok } \\
\text { pembelajaran }\end{array}$ & Siklus I & $\frac{19}{24} \times 100 \%=79,17 \%$ \\
\cline { 2 - 3 } & Siklus II & $\frac{23}{24} \times 100 \%=92 \%$ \\
\hline $\begin{array}{l}\text { Ketepatan dan ketelitian dalam } \\
\text { mengerjakan soal }\end{array}$ & Siklus I & $\frac{17}{24} \times 100 \%=70,83 \%$ \\
\cline { 2 - 3 } & Siklus II & $\frac{22}{25} \times 100 \%=88 \%$ \\
\hline Ketuntasan hasil belajar & Siklus I & $\frac{20}{24} \times 100 \%=83,33 \%$ \\
\cline { 2 - 3 } & Siklus II & $\frac{23}{25} \times 100 \%=92 \%$ \\
\hline
\end{tabular}

Tabel diatas apabila di tuangkan kedalam sebuah diagram dapat dilihat pada gambar 1 di bawah ini.

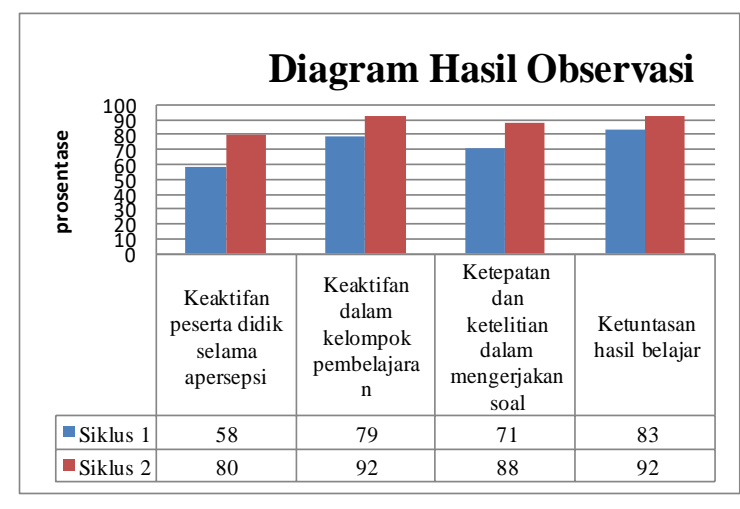

Gambar 1. Diagram hasil observasi pada siklus 1 dan siklus 2
Tabel dan diagram di atas menunjukkan bahwa setelah adanya penerapan metode tutor sebaya berdampak terhadap proses dan hasil kegiatan pembelajaran matematika. Dampak positif tersebut antara lain peserta didik lebih memahami materi yang disampaikan oleh pendidik, peserta didik menjadi lebih aktif dan bersemangat dalam mengikuti proses pembelajaran dan pesrta didik dapat bekerjasama dalam kelompok dengan pesrta didik yang lain serta mendiskusikan hasil pekerjaannya. Selain itu, hasil belajar pesrta didik mengalami peningkatan.

.Dari hasil pengamatan terhadap proses belajar mengajar matematika pada siklus pertama masih terdapat kekurangan 
dan kelemahan, yaitu peserta didik kurang aktif dalam mengikuti pembelajaran. Hal ini dapat dilihat dari respon pesrta didik pada saat apersepsi dan dominasi beberapa peserta didik dalam mengemukakan pendapatnya selama proses pembelajaran berlangsung. Selain itu, kesempatan tanya jawab yang diberikan pendidik juga cukup terbatas. Karena itu, peneliti mencari solusi dan menyusun rencana pembelajaran siklus kedua untuk mengatasi kekurangan dan kelemahan dalam pembelajaran akuntansi pada siklus pertama.

Materi pembelajaran pada siklus kedua berbeda dengan siklus pertama yaitu Perkalian scalar dua vector pada ruang dimensi tiga. Dalam siklus ke kedua ini, pendidik membagi pesrta didik dalam kelompok-kelompok kecil untuk menyelesaikan latihan soal yang diberikan oleh pendidik. Selain itu siklus kedua dilaksanakan didasarkan atas perbaikan dari kelemahan siklus pertama. Pada saat menanyakan pada pesrta didik, pesrta didik merasa cukup tertarik dengan pembelajaran menggunakan metode tutor sebaya, selain pesrta didik menjadi aktif, pesrta didik juga merasa lebih bisa memahami materi karena selain pendidik memberikan penjelasan materi secara bertahap, pendidik juga memberikan latihan soal-soal kepada pesrta didik. Selain itu, pesrta didik juga diajarkan untuk bekerja secara kelompok dalam menyelesaikan latihan soal. Dengan cara ini, pesrta didik menjadi lebih aktif karena selain dapat bertanya langsung kepada pendidik, peserta didik juga dapat bertanya dengan bantuan tutor dari teman mereka dalam kelompok.

Berdasarkan hasil pengamatan
terhadap proses belajar mengajar matematikai pada siklus kedua, prestasi belajar baik hasil maupun proses sudah menunjukkan peningkatan. Dari segi keaktifan peserta didik dalam apersepsi menunjukkan peningkatan dari $58,44 \%$ atau 14 pesrta didik pada siklus pertama menjadi $80,00 \%$ atau 20 pesrta didik pada siklus kedua. Selama proses pembelajaran berlangsung peserta didik yang menunjukkan keaktifan mereka sebanyak 19 peserta didik atau $79,17 \%$ pada siklus pertama sedangkan pada siklus kedua sebanyak 23 peserta didik atau 92,00\%. Dalam ketepatan dan ketelitian menyelesaikan soal pada siklus pertama terdapat 17 peserta didik atau $70,83 \%$, sedangkan pada siklus kedua terdapat 22 peserta didik atau $88,00 \%$. Begitupula pada ketuntasan hasil belajar peserta didik peningkatan ini ditunjukkan dari banyaknya peserta didik yang sudah mencapai kriteria ketuntasan minimal yaitu sebesar 83,33\% atau sebanyak 20 peserta didik pada siklus pertama dan $92,00 \%$ atau sebanyak 23 peserta didik pada kedua. Peserta didik yang sebelumnya kurang aktif saat pembelajaran, sekarang menjadi lebih antusias dalam proses pembelajaran. Selain itu peserta didik yang sebelumnya tidak bisa bekerjasama dalam kelompok, pada siklus kedua ini sudah dapat bekerjasama dengan peserta didik lain dengan baik (tanpa harus memilih). Meskipun begitu, masih diperlukan juga motivasi dan pendekatan dari pendidik untuk mendukung berhasilnya proses belajar mengajar matematika. Oleh sebab itu masalah yang dihadapi pada pembelajaran matematika konsep perkalian scalar dua vector sudah dapat teratasi dengan cara penerapan metode tutor sebaya yang secara langsung dapat meningkatkan pemahaman pesreta didik, mengaktifkan peserta didik dalam proses pembelajaran dan meningkatkan hasil belajar peserta didik.

Berdasarkan tindakan tersebut, pendidik berhasil melaksanakan pembelajaran matematika yang dapat menarik perhatian peserta didik, sehingga kualitas proses dan hasil pembelajaran dapat meningkat. Selain itu, peneliti juga dapat meningkatkan motivasi dan kinerja pendidik dalam melaksanakan pembelajaran yang efektif, menarik, dan menyenangkan. Keberhasilan pembelajaran matematika dengan menggunakan metode tutor sebaya dapat dilihat dari indikator-indikator sebagai berikut: 1) Peserta didik makin antusias pada saat awal akan mengikuti kegiatan belajar mengajar dan selama mengikuti kegiatan belajar mengajar, 2) Peserta didik bersemangat dalam berperan mengajar teman sekelompoknya, 3) Peserta didik merasa mendapatkan tanggung jawab, 
karena dituntut untuk dapat mengerjakan soal di dalam kelompoknya, 4) Peserta didik sudah mampu menguasai konsep materi matematika dengan konsep perkalian scalar dua vector, ditunjukkan dengan peningkatan prosentase ketuntasan dari siklus pertama ke siklus kedua, 5) Nilai tes yang telah diberikan pendidik menunjukkan peningkatan dari siklus pertama sampai siklus kedua yang memberikan indikasi adanya usaha peserta didik ke arah yang lebih baik.

Diagram berikut menunjukkan peningkatan prestasi belajar peserta didik dari siklus 1 ke siklus 2, yang melihat dari segi peningkatan rata-rata kelas, daya serap dan ketuntasan belajar.

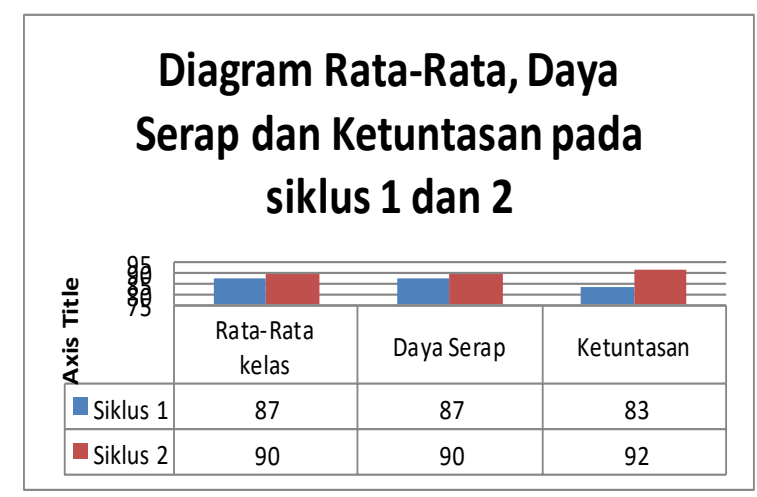

Gambar 2. Diagram rata-rata, daya serap dan ketuntasan belajar pada siklus 1 dan siklus 2

Jadi dari pemaparan diatas dapat disimpulkan bahwa penerapan metode pembelajaran tutor sebaya dapat meningkatkan prestasi pembelajaran matematika konsep perkalian skalar dua vektor bagi peserta didik semester 2 MIPA SMA Swasta Katolik Bhaktyarsa Tahun 2018. Penelitian ini sejalan dengan penelitian yang dilkukan oleh Indriani (2014) yang menunjukkan bahwa penerapan metode pembelajaran tutor sebaya (peer tutoring) dapat meningkatkan hasil belajar siswa pada mata diklat menyusun laporan keuangan pada siswa kelas XI Keuangan 1 SMK Negeri 1 Pamekasan. Penelitian oleh Muthea (2015) menunjukkan bahwa metode totur sebaya dapat meningkatkan hasil aktivitas belajar siswa.
Beberapa kemungkinan penyebab dari pembelajaran model tutor sebaya dapat memberikan hasil yang baik dapat dikemukakan sebagai berikut: Pertama, seorang peserta didik yang pandai dapat membantu belajar peserta didik lainnya dalam tingkat kelas yang sama. Kedua, bahasa Inggris dianggap oleh peserta didik pelajaran yang sulit adalah bahasa yang digunakan oleh gurunya, sehingga dalam hal tertentu peserta didik lebih paham dengan bahasa teman sebayanya daripada bahasa gurunya. Ketiga, pembelajaran tutor sebaya terpusat pada peserta didik, sehingga dalam hal ini peserta didik belajar dari peserta didik lain yang memiliki status umur, kematangan/harga diri yang tidak jauh berbeda dari dirinya sendiri, keempat, peserta didik yang lebih mudah bertanya, lebih terbuka dengan teman sendiri dibandingkan dengan gurunya, sebagaimana yang dikemukakan oleh Suyitno ( 2004) bahwa metode yang paling baik adalah dengan mengajarkan kepada orang lain yaitu pemilihan model tutor sebaya akan sangat membantu peserta didik dalam mengajarkan materi kepada teman-temannya. Disiplin diri yang diberikan peserta didik dengan didasari oleh motivasi yang positif dari internal dan eksternal peserta didik, baik yang prestasinya tinggi maupun peserta didik yang prestasinya rendah demi terciptanya suatu kondisi yang tepat bagi peserta didik untuk secara maksimal menerima bahan ajaran, sehingga tugas yang diberikan seorang guru tidak dianggap sebagai suatu beban.

\section{SIMPULAN DAN SARAN}

Dari hasil penelitian yang telah dilakukan, maka dapat disimpulkan : "Penerapan metode pembelajaran tutor sebaya dapat meningkatkan prestasi pembelajaran matematika konsep perkalian skalar dua vektor bagi peserta didik semester 2 MIPA SMA Swasta Katolik Bhaktyarsa Tahun 2018".

Untuk menyempurnakan hasil yang diperoleh dalam penenelitian ini maka perlu dajukan beberapa saran seberikut : 1 . 
Metode pembelajaran tutor sebaya dapat meningkatkan keaktifan peserta didik dalam pembelajaran matematika, konsep perkalian scalar dua vector sehingga dapat dijadikan sebagai alternatif metode pembelajaran matematika untuk materi yang lain, 2. Perlu dilakukan penelitian lanjutan untuk kelas yang berbeda dan materi yang berbeda , karena metode ini memotivasi peserta didik untuk aktif dalam kegiatan pembelajaran

\section{DAFTAR RUJUKAN}

Ali, Muhammad, 2002. Guru Dalam Proses Belajar Mengajar, Bandung : Sinar Baru

Asmani, J A. (2011). 7 Tips Aplikasi Pakem; (Pembelajaran Aktif, Kreatif, Efektif, dan Menyenangkan). Jogjakarta : Diva Press.

Djamarah, Syaiful, Bahri , 2000. Guru dan Anak Didik Dalam Interaksi Edukatif. Jakarta : Rineka Cipta

Djamarah, Syaiful, Bahri , 2000. Strategi Belajar Mengajar. Jakarta : Rineka Cipta

Depdiknas, 2014. Pedoman Pengembangan Penilaian. Yogyakarta : Depdiknas

Hudojo, Herman, 2000. Strategi Mengajar Matematika, Bandung : IKIP.

Hendriansyah, Dede, Rita Milyartini, Engkur Kurdita. 2013. Penerapan Metode Pembelajaran Tutor Sebaya Dalam Meningkatkan Keterampilan Bermain Ornamen Suling Lubang Enam. Jurnal Jurusan Pendidikan Seni Musik Fakultas Pendidikan Bahasa dan Seni Universitas Pendidikan Indonesia Volume 1 Nomor 3.

Indriani, Angela Merici Fina , Siti Mutmainnah. 2014. Metode Pembelajaran Tutor Sebaya Sebagai Upaya Meningkatkan Hasil Belajar Siswa. Journal of Accounting and Business Education Volume 2 Nomor 4.
Indrianie, Niken Sholi. 2015. Penerapan Model Tutor Sebaya pada Mata Pelajaran Bahasa Inggris Reported Speech terhadap Hasil Belajar Peserta didik MAN Kota Probolinggo. Jurnal Kebijakan dan Pengembangan Pendidikan Volume 1, Nomor 1.

Munthe, Lamhot. 2015. Penerapan Model Pembelajaran Tutor Sebaya Untuk Meningkatkan Aktivitas Belajar Siswa Pada Mata Pelajaran Matematika Di Kelas Iv Sd Negeri 101740 Tanjung Selamat. Jurnal Handayani volume 3 Nomor 2.

Nera, Aprina, 2014. Perbandingan Metode Sokratis dan Tanya Jawab Terhadap Hasil Pembelajaran Matematika. Palembang : Universitas PGRI.

Nurmala, Sukayasa, dan Baharuddin Paloloang. 2017. Penerapan Model Pembelajaran Tutor Sebaya Untuk Meningkatkan Hasil Belajar Siswa Kelas V SDN 20 Toli-Toli Pada Operasi Hitung Campuran Bilangan Bulat. Jurnal Kreatif Tadulako Online Vol. 4 No. 9

Idarta, Made, 2008. Cara Belajar Mengajar di Universitas Negara Maju. Jakarta : Bumi Aksara

Simanjuntak, Lisnawaty, dkk, 2003 Metode Mengajar Matematika,. Jakarta : Rineka Cipta

Sudjana, 2002. Metode Statistika. Bandung : Tarsito

Sunhaji. (2009). Strategi Pembelajaran, Konsep Dasar, Metode, dan Aplikasi dalam Proses Belajar Mengajar. Yogyakarta: Grafindo Litera Media.

Suyitno, I. (2011). Memahami Tindakan Pembelajaran; Cara Mudah dalam Perencanaan PTK. Bandung: PT. Refika Aditama. 